\title{
Discovery and creation: alternative theories of entrepreneurial action
}

\section{Descoberta e criação: teorias alternativas à ação empreendedora}

SHARON A. ALVAREZ*

JAY B. BARNEY**

\section{Abstract}

Do entrepreneurial opportunities exist, independent of the perceptions of entrepreneurs, just waiting to be discovered? Or, are these opportunities created by the actions of entrepreneurs? Two internally consistent theories of how entrepreneurial opportunities are formed-discovery theory and creation theory-are described. While it will always be possible to describe the formation of a particular opportunity as an example of a discovery or creation process, these two theories do have important implications for the effectiveness of a wide variety of entrepreneurial actions in different contexts. The implications of these theories for seven of these actions are described, along with a discussion of some of the broader theoretical implications of these two theories for the fields of entrepreneurship and strategic management

Keywords: entrepreneurship theory; opportunity creation; opportunity discovery; uncertainty.

* Fisher College of Business-Columbus, Ohio, E-mail: Alvarez_42@cob.osu.edu

** Fisher College of Business-Columbus, Ohio, E-mail: Alvarez_42@cob.osu.edu 


\section{Resumo}

As oportunidades empreendedoras existem independentemente das percepções dos empreendedores, esperando apenas para serem descobertas? Ou essas oportunidades são criadas pelas ações dos empreendedores? Duas teorias, internamente consistentes com as oportunidades empreendedoras, são: a da criação e a da descoberta - as quais serão descritas. Enquanto for sempre possível descrever a formação de uma oportunidade particular, como exemplo, de um processo da descoberta ou da criação de oportunidade, essas duas teorias terão implicações importantes para a eficácia de ampla variedade de ações empreendedoras em contextos diferentes. As implicações dessas teorias para sete dessas ações serão descritas, acompanhadas de discussão sobre algumas das implicações teóricas mais amplas para os campos do empreendimento e do gerenciamento estratégico.

Palavras-chave: teoria do empreendimento; criação da oportunidade; descoberta da oportunidade; incerteza.

\section{INTRODUCTION}

When asked why he climbed Mount Everest, world renowned mountain climber George Mallory is alleged to have responded, "Because it is there." Many entrepreneurship scholars have adopted a similar metaphor when talking about why entrepreneurs exploit competitive opportunities - because they are there. Because these opportunities exist, and because some people are more insightful or clever in recognizing and exploiting opportunities than others, exploiting these opportunities can be a source of economic profits and, in some cases, fame and fortune.

Assuming that opportunities - like mountains - exist as objective phenomena just waiting to be discovered and exploited has important implications for entrepreneurial actions. For example, if opportunities exist as objective phenomena, then the task of ambitious entrepreneurs is to discover these opportunities - using whatever data collection techniques exist-and then exploit them-using whatever strategies are required-all as quickly as possible, before another entrepreneur discovers and exploits the opportunity. Just as few remember the second person to conquer Mount Everest, entrepreneurs that are late in discovering and exploiting an oppor- 
tunity will generally not experience the same success as the first entrepreneurs to successfully discover and exploit an opportunity. But, what if entrepreneurial opportunities were not like mountains, just waiting to be discovered and exploited. Suppose, instead, that these competitive imperfections in markets were created by the actions of entrepreneurs. In this case, the right metaphor for entrepreneurship is not "mountain climbing" but, rather, "mountain building." And, assuming that opportunities are created rather than discovered may also have very important implications for entrepreneurial action. For example, rather then searching for a clear opportunity to be exploited, entrepreneurs creating opportunities might engage in an iterative learning process that ultimately could lead to the formation of an opportunity. In the former case, entrepreneurs would spend a great deal of time and energy developing a single, comprehensive and complete, business plan. In the latter case, entrepreneurs may find that business plans can only be written after an opportunity has been created, and that rigorous planning too early in this process can be, at best, a waste of resources, and at worst, fundamentally misleading - to both entrepreneurs and those that invest in them.

The purposes of this paper are, first, to describe the theories of entrepreneurship that underlie these two metaphors-mountain climbing and mountain building - and second, to understand the implications for the actions of entrepreneurs associated with these theories. The paper begins by examining the kinds of assumptions that all teleological theories of human action, including teleological theories of entrepreneurial action, must make. These assumptions are then used as a basis for describing a "discovery" mountain climbing approach to entrepreneurship, and then describe the "creation" a mountain building approach to entrepreneurship. Each of these theories, it will be shown, are internally consistent. Also, it will always be possible after an opportunity is formed to describe the actions of a particular entrepreneur in both "discovery" and "creation" terms. Thus, debates about whether an opportunity is a "discovery" or "creation" opportunity, by themselves, are without empirical content. However, these theories do have empirical content when entrepreneurs act based on one theory or the other. Thus, after describing these two theories, much of the paper focuses on the implications that they each have for the effectiveness of a variety of entrepreneurial actions in different settings. 


\section{TEleOlogical THEORIES OF ENTREPRENEURIAL ACTION}

Teleological theories of human action explain human behavior in terms of the impact of that behavior on the ability of individuals to accomplish their purposes. In general, these theories assert that behavior that facilitates the accomplishment of one's purposes is more likely to occur than behavior that does not facilitate the accomplishment of one's purposes (Parsons and Shils, 1962). Examples of teleological theories in the social sciences include motivation theory in psychology (Herzberg, 1976; Maslow, 1943), functional theory in anthropology (Lesser, 1935), and institutional theory in sociology (DiMaggio and Powell, 1983; Scott, 2001).

As a matter of logic, all teleological theories of human action must make three critical assumptions: (1) assumptions about the nature of human objectives, (2) assumptions about the nature of individuals, and (3) assumptions about the nature of the decision making context within which individuals operate (Bergmann, 1957; Nagal, 1961; Parsons, 1951; Parsons and Shils, 1962). When different teleological theories generate different predictions about the same human actions, these different predictions usually turn on one or more differences in these three critical assumptions (Parsons and Shils, 1962). For this reason, these three assumptions are an effective basis upon which to compare and contrast different teleological theories of human action.

Both of the theories identified in this paper-discovery theory and creation theory-are examples of teleological theory and thus have much in common. ${ }^{1}$ For example, they both seek to explain the same dependent variable-actions that entrepreneurs take to form and exploit opportunities. In this context, entrepreneurial action is defined as any activity entrepreneurs might take to form and exploit opportunities (Shane, 2003: 4; Shane and Venkataraman, 2000, 211). Moreover, as teleological theories, both discovery and creation seek to explain these entrepreneurial actions in terms of their impact on the ability of entrepreneurs to form and exploit opportunities.

However, while discovery and creation theory have much in common, they often generate different predictions about when spe-

\footnotetext{
While discovery and creation theory are both teleological theories, not all theories of entrepreneurial action must be teleological. For example, an evolutionary theory of entrepreneurial action could be developed that does not depend on entrepreneurs engaging in actions in an effort to produce new products or services. Examples of these kinds of models can be found in Nelson and Winter (1982) and Hannan and Freeman (1977).
} 
cific entrepreneurial actions will be more or less effective in enabling entrepreneurs to form opportunities. As was suggested earlier, when different teleological theories generate different predictions about the same human actions - in this case, entrepreneurial actions - these different predictions usually turn on one or more differences in the three critical assumptions that all teleological theories must make. Thus, these three assumptions are used as a basis for comparing and contrasting discovery and creation theory in the remainder of this paper.

\section{Discovery THEORY}

Of the two theories discussed in this paper, discovery theory has received much more attention in the literature (Gaglio and Katz, 2001; Shane, 2003; Venkataraman, 2003). The three critical assumptions of discovery theory as presented in this literature are summarized in Table 1.

Table 1 - Central Assumptions of Discovery and Creation Theories of Entrepreneurial Action

\begin{tabular}{|c|c|c|}
\hline & Discovery Theory & Creation Theory \\
\hline Nature of Opportunities & $\begin{array}{l}\text { Opportunities exist, } \\
\text { independent of } \\
\text { entrepreneurs. Applies a } \\
\text { realist philosophy. }\end{array}$ & $\begin{array}{l}\text { Opportunities do not exist } \\
\text { independent of } \\
\text { entrepreneurs. Applies an } \\
\text { evolutionary realist } \\
\text { philosophy. }\end{array}$ \\
\hline Nature of Entrepreneurs & $\begin{array}{l}\text { Differ in some important } \\
\text { ways from non } \\
\text { entrepreneurs, ex ante. }\end{array}$ & $\begin{array}{l}\text { May or may not differ from } \\
\text { non entrepreneurs, ex ante. } \\
\text { Differences may emerge, ex } \\
\text { post. }\end{array}$ \\
\hline $\begin{array}{l}\text { Nature of Decision Making } \\
\text { Context }\end{array}$ & Risky & Uncertain \\
\hline
\end{tabular}

\section{Discovery Objectives}

As suggested earlier, both discovery theory and creation theory assume that the goal of entrepreneurs is to form and exploit opportunities (Shane and Venkatraman, 2000: 211; Shane, 2003: $4)$. Both theories also recognize that opportunities exist when competitive imperfections exist in a market or industry. However, these two theories differ in their analysis of the origin of these competitive imperfections. In discovery theory, competitive im- 
perfections are assumed to arise exogenously, from changes in technology, consumer preferences, or some other attributes of the context within which an industry or market exists (Kirzner, 1973, $10) .{ }^{2}$ In his review of this literature, Shane $(2003,23)$ cites technological changes, political and regulatory changes, and social and demographic changes as examples of the kinds of events that can disrupt the competitive equilibrium that exists in a market or industry, thereby forming opportunities.

This emphasis on exogenous shocks forming opportunities has several important implications for discovery theory. For example, this emphasis suggests that discovery theory is based on realist assumptions in the philosophy of science-that opportunities, like mountains, exist as real and objective phenomena, independent of the actions or perceptions of entrepreneurs, just waiting to be discovered and exploited (McKelvey, 1999). Just as Mount Everest existed before George Mallory climbed it, that discovery opportunities are yet to be observed does not deny the reality of their existence. However, it is entrepreneurs who bring "agency to opportunity" (Shane, 2003, 7) by exploiting them.

Also, this emphasis on exogenous shocks forming opportunities suggests that discovery theory is predominantly about search-systematically scanning the environment to discover opportunities to produce new products or services. In this search process, entrepreneurs must consider both its direction and duration, and must also guard against confusing local search-where modest opportunities to produce new products or services exist - with more global searchwhere much more substantial opportunities exist (Levinthal, 1997).

\section{DisCOVERY ENTREPRENEURS}

The assumption made by discovery theory concerning the nature of entrepreneurs follows directly from its assumption about the nature of opportunities. Since opportunities are created by exogenous shocks to an industry or market and since these opportunities are objective and thus, in principle, observable, then everyone associated with that industry or market should be aware of the oppor-

2 There is another type of opportunity called opportunity recognition that is not discussed in this paper. According to Miller (this issue), opportunity recognition can be thought of as a form of arbitrage where an entrepreneur recognizes an existing unmet demand and matches it with a known product. 
tunities a shock has created. Of course, if everyone associated with an industry or market knew about the opportunities created by a shock, and were all sufficiently skilled to exploit these opportunities, then they could all try to exploit them.

In a setting where everyone could potentially become aware of and exploit an opportunity, it would be difficult for anyone to generate sufficient profits from actually producing new products or services (Barney, 1986; Schumpeter, 1939). Thus, in order to explain why entrepreneurs associated with an industry or market are willing and able to exploit opportunities while non entrepreneurs are not, discovery theory must necessarily assume that entrepreneurs who discover opportunities are significantly different from others in their ability to either see opportunities or, once they are seen, to exploit these opportunities (Kirzner, 1973; Shane, 2003).

Kirzner $(1973,67)$ summarizes the differences between entrepreneurs and non entrepreneurs with the concept of "alertness". Many potential components of alertness have been identified in the literature, including information asymmetries, different risk preferences, and cognitive differences, among others (Shane, 2003). Any of these attributes, or any combination of these attributes, might lead some entrepreneurs associated with an industry or market to become aware of opportunities created by exogenous shocks, while others associated with that same industry or market may remain ignorant of these opportunities.

While empirical research on systematic differences between entrepreneurs and non entrepreneurs has continued for well over two decades, the results of this work have been mixed, overall (Low and MacMillan, 1988; McClelland, 1961). In their extensive review of this literature, Busenitz \& Barney (1997) conclude that the evidence about whether or not entrepreneurs are systematically different than non entrepreneurs is not compelling with the exception of work on cognition. And even this cognitive work does not yet show whether cognitive differences exist before the entrepreneurs begin engaging in entrepreneurial actions or if these differences emerge as a result of the experiences of entrepreneurs while forming opportunities.

\section{DISCOVERY DECISION MAKING CONTEXT}

Finally, the decision making context within which entrepreneurs choose to exploit an opportunity is assumed, by discovery theory, to be risky, rather than uncertain. Currently, these terms are 
often used interchangeably in the entrepreneurship (Shane, 2003: 7) and strategic management (Balakrishnan and Wernerfelt, 1986; Wernerfelt and Karnani, 1987) literatures. However, for purposes of distinguishing between the assumptions of discovery theory and creation theory, these terms have distinct meanings (Knight, 1921). ${ }^{3}$

A decision making context is risky if, at the time a decision is being made, decision makers can collect enough information about a decision to anticipate possible outcomes associated with that decision, and the probability of each of those possible outcomes. A decision making context is uncertain if, at the time a decision is being made, decision makers cannot collect the information needed to anticipate either the possible outcomes associated with a decision nor the probability of those outcomes. ${ }^{4}$

The decision making context in discovery theory is risky because it assumes that opportunities are objective in nature. As objective phenomena, entrepreneurs can use a variety of data collection and analysis techniques to understand the possible outcomes associated with an opportunity, along with the probability of those outcomes. It may take some time and effort to complete these analyses, but, in principle, they can be done when an opportunity is objective in nature. It took many decades to discover the existence of Mount Everest, and still many additional decades to measure its height. But despite these challenges, there was never a question about whether or not, in principle, information about this mountain was collectable.

\section{Creation Theory}

Creation theory is a logical theoretical alternative to discovery theory for explaining the actions that entrepreneurs take to form and exploit opportunities (Aldrich and Kenworthy, 1999; Aldrich and Ruef, 2006; Gartner, 1985; Venkataraman, 2003). Aspects of creation theory have been described by a variety of authors (Alvarez and Barney, 2005; Baker and Nelson, 2005; Casson, 1982;

3 The decision making settings defined refer to objective properties of a particular decision making context, not to an entrepreneurs' beliefs about those contexts (Alvarez \& Barney, 2005).

4 A third decision making context-ambiguity-can also be identified (Dequech, 2003). This exists when the outcomes associated with a decision can be known at the time a decision is made, but the probability of these outcomes cannot be known. To simplify this discussion, ambiguity is treated as a special case of uncertainty in this paper. 
Gartner, 1985; Langlois and Cosgel, 1993; Loasby, 2002; Sarasvathy, 2001; Schumpeter, 1934). However, unlike discovery theory, creation theory has yet to be articulated as a single coherent theory in the literature. The central organizing assumptions of this theory are also summarized in Table 1.

\section{Creation objectives}

In creation theory, opportunities are not assumed to be objective phenomena formed by exogenous shocks to an industry or market. Rather, they are created, endogenously, by the actions, reactions, and enactment of entrepreneurs exploring ways to produce new products or services (Baker and Nelson, 2005; Gartner, 1985; Sarasvathy, 2001; Weick, 1979). This endogenous view of opportunities has a variety of implications for creation theory.

In creation theory, opportunities do not necessarily evolve out of pre-existing industries or markets (Dosi, 1984, 1988; Etzioni, 1963). The term "search" has little or no meaning in creation theory. "Search" implies entrepreneurs attempting to discover opportunities - like mountains - that already exist. In creation theory, entrepreneurs do not search - for there are no mountains to find - they act, and observe how consumers and markets respond to their actions. While, ex post, after an opportunity has been exploited, it will always be possible to show how that opportunity evolved out of a prior industry or market, creation theory suggests that, ex ante, before an opportunity is created, its links with prior industries or markets are unknown. That is, creation theory suggests that the "seeds" of opportunities to produce new products or services do not necessarily lie in previously existing industries or markets.

In creation theory, "bringing agency to opportunities" is without meaning since opportunities do not exist independently of the actions taken by entrepreneurs to create them (Weick, 1979). In this view instead of being passive with respect to the formation of new opportunities, creation theory assumes that entrepreneur's actions are the essential source of these opportunities - they build the mountains. In this model, entrepreneurs do not wait for exogenous shocks to form opportunities and then provide agency to those opportunities, they act (Baker and Nelson, 2005; Bhide, 1999; Sarasvathy, 2001). And in acting, they form opportunities that could not have been known without the actions taken by these entrepreneurs. 
Creation opportunities are social constructions that do not exist independent of entrepreneur's perceptions (Aldrich and Kenworthy, 1999; Berger and Luckmann, 1967). However when entrepreneurs act to exploit these socially constructed opportunities, they interact with an environment-the market-that tests the veracity of their perceptions. Of course, the market is, itself, a social construction, formed out of the perceptions and beliefs of numerous other individuals. This form of analysis suggests that creation theory is grounded in what has come to be known as the evolutionary realist perspective in the philosophy of science (Azevedo, 2002; Campbell, 1960; McKelvey, 1999).

This enactment process is consistent with evolutionary theories of entrepreneurial action (Aldrich and Ruef, 2006; Campbell, 1960; Weick, 1979). In both evolutionary theory and creation theory, a blind-variation - an action that emerges without any self-conscious planning or foresight - can begin a process of action and reaction that leads to the formation of opportunities (Aldrich and Kenworthy, 1999). Of course, in creation theory, actions need not be "completely blind". They may be deliberate or intelligent or even a random variation that starts the process. However, variations are likely to be quite myopic. The notion of blind-variation emphasizes changes in unforeseen and perhaps even unwanted ways (Campbell, 1960). Rarely will entrepreneurs be able to see "the end from the beginning." In this view there is no "end" until the creation process has unfolded, i.e., opportunities cannot be understood until they exist, and they only exist after they are enacted in an iterative process of action and reaction (Berger and Luckmann, 1967; Weick, 1979). Blind or myopic variations in creation theory are the raw materials from which selection processes cull those that are most suitable (Aldrich and Ruef, 2006).

As they begin to take action to form opportunities, entrepreneur's beliefs, formed on the path the variations have taken them on, can become social constructs that guide subsequent actions of these entrepreneurs and others associated with an industry or market-including customers and suppliers (Berger and Luckmann, 1967; Weick, 1979). As entrepreneurs act upon their initial beliefs about opportunities and then observe the market responses, beliefs are transformed reflecting the acquisition and creation of knowledge and information (Arrow, 1974). Most frequently, entrepreneurs learn that their original beliefs about the nature and scope of what 
they thought were opportunities are not justified. These entrepreneurs are then forced to develop new beliefs about opportunities that build on what they learned (Choi, 1993). Often, entrepreneurs learn that these additional beliefs about an opportunity are also not justifiable, and are forced to rethink their beliefs. Indeed, after several iterative actions, evaluations, and reactions, entrepreneurs may even decide that they misinterpreted the results of previous actions and go back several sequences and start again or even abandon the entire process altogether (Cyert and March, 1963; March and Simon, 1958; Mosakowski, 1997).

This creation process is clearly path dependent, in that small differences in initial decisions and choices made by entrepreneurs can lead to large differences over time (Arthur, 1989). Path dependent processes also play an important role in other social science theories, including resource-based theory in strategic management (Barney, 1991; Dierickx and Cool, 1989). In a sense, these theories emphasize the importance of information and knowledge generated from the process of enacting an opportunity. As that process evolves differently for different entrepreneurs, the opportunities that result may be heterogeneous in costly-to-copy, and costly-toreverse ways.

\section{Creation entrepreneurs}

A central assumption of discovery theory is that entrepreneurs who form and exploit opportunities are significantly different than those entrepreneurs who do not form and exploit opportunities. This assumption is necessary in order to explain why everyone associated with an industry or market is not aware of and/or unable to exploit opportunities in this industry or market. Differences between entrepreneurs and non entrepreneurs play a very different role in creation theory.

First, creation theory suggests that, ex ante, before entrepreneurs create opportunities, they may or may not be significantly different than those who do not create opportunities. If significant differences - of the type assumed in discovery theory - exist, these differences can explain why some entrepreneurs form opportunities and others do not.

Alternatively, creation theory acknowledges that even very small differences between entrepreneurs and non entrepreneurs, ex ante, could lead some to form opportunities and others not to form oppor- 
tunities. For example, two individuals may be indistinguishable with respect to their attributes, but small variations in their local environment-e.g., differences in location-might lead one of them to form and exploit an opportunity. Luck (Barney, 1986) can play a significant role in this highly path dependent process (Arthur, 1989).

However, while creation theory is agnostic about the significance of ex ante differences between these entrepreneurs and non entrepreneurs, this theory does acknowledge that the process of creating opportunities can exacerbate what were initially small differences and make them large differences. Consider, for example, the cognitive attributes of entrepreneurs documented by Busenitz and Barney (1997). Creation theory suggests that individuals may be virtually indistinguishable, in terms of their cognitive characteristics, before the creation process begins. However, those that take a more entrepreneurial path over time may find that certain cognitive attributes-including a systematic overconfidence and a willingness to generalize from small samples-are more positively reinforced than other cognitive attributes. This process can create significant differences, ex post, between individuals who form and exploit opportunities and individuals who do not. In this sense, differences between these groups may be the result of the entrepreneurial path taken, not just a cause of entrepreneurship (Hayward, Shepherd and Griffin, 2006; Sarasvathy, 2001).

\section{Creation Decision making CONTEXT}

The decision making context in creation theory is uncertain. This is because, according to this theory, opportunities do not exist until they are created. At the point a decision about whether or not to try to form an opportunity is made, the information required to know the possible outcomes associated with this decision, and their probability, does not yet exist. In principle, no matter how hard an entrepreneur works, all the information needed to turn this decision making setting into a risky one cannot be collected. The inability to estimate the probability distributions associated with making decisions, under creation theory, does not depend on the limited time that potential entrepreneurs have had to collect information about a new opportunity, nor on the ability of potential entrepreneurs to analyze the information they have collected - as is assumed in discovery theory. Rather, under uncertainty, even entrepreneurs with a great deal of time, or with unusual analytical abilities, will not be 
able to estimate the relevant probability distributions (Dunning, Heath and Suls, 2004; Miller, 2007). The information required to estimate these distributions, ex ante, simply has not been created yet. Put differently, it is not possible to measure the height of a mountain that has not yet been created.

Of course, this does not mean that entrepreneurs operating in creation settings will be unable to collect at least some information, ex ante, about certain courses of action. That is, in the midst of forming creation opportunities, entrepreneurs may be able to collect and analyze information about discovery opportunities. However, for those opportunities that are being formed by the actions of entrepreneurs, such information does not yet exist, and therefore, it cannot be collected or analyzed.

\section{DISCOVERY AND CREATION IMPLICATIONS FOR EFFECTIVE ENTREPRENEURIAL ACTIONS}

As suggested in Table 1, the assumptions underlying discovery and creation theory are both internally consistent, though largely contradictory. However, debates about which of these sets of assumptions, per se, most accurately represents reality are not likely to be resolvable ex post since, in principle, it will always be possible to interpret the formation of a particular opportunity as either a discovery or creation process. Rather, these sets of assumptions only have empirical implications when they are linked with specific entrepreneurial actions: discovery theory suggests that certain actions are more likely to be effective then creation theory, and vice versa.

In this sense, the actions that entrepreneurs actually take can be thought of as a manifestation of the assumptions they make about the nature of the context within which they are operating-is it a discovery context or a creation context. If their hypothesis about the nature of this context is correct, and the theory they are applying is correct in its implications, then that activity will be relatively effective in the formation and exploitation of an opportunity. If their hypothesis about the nature of their context is incorrect, and they end up applying the wrong theory, then that activity will be relatively ineffective in the formation and exploitation of an opportunity.

For these reasons, understanding the implications of these two sets of assumptions for the effectiveness of a wide variety of entrepreneurial actions is important. The implications of discovery and creation assumptions for seven of these actions are discussed here 
and summarized in Table 2 . These seven were chosen because they are generally cited as important considerations for all types of entrepreneurs seeking to form and exploit opportunities, whether operating in a discovery or creation context.

Table 2 - Effective Entrepreneurial Actions in Discovery and Creation Contexts

\begin{tabular}{|c|c|c|}
\hline & Discovery Context & Creation Context \\
\hline Leadership & $\begin{array}{l}\text { Based on expertise } \\
\text { and (perhaps) experience }\end{array}$ & Based on charisma \\
\hline Decision Making & $\begin{array}{l}\text { Risk-based data collection } \\
\text { tools; Risk-based decision } \\
\text { making tools; Importance of } \\
\text { opportunity costs }\end{array}$ & $\begin{array}{l}\text { Iterative, inductive, } \\
\text { incremental decision } \\
\text { making; Use of biases and } \\
\text { heuristics; importance of } \\
\text { affordable loss }\end{array}$ \\
\hline Human Resource Practices & $\begin{array}{l}\text { Recruitment: Specific } \\
\text { human capital recruited } \\
\text { broadly }\end{array}$ & $\begin{array}{l}\text { Recruitment: General and } \\
\text { flexible human capital } \\
\text { recruited from pre-existing } \\
\text { social networks }\end{array}$ \\
\hline Strategy & $\begin{array}{l}\text { Relatively complete and } \\
\text { unchanging }\end{array}$ & Emergent and changing \\
\hline Finance & $\begin{array}{l}\text { External capital sources: } \\
\text { Banks and venture capital } \\
\text { firms }\end{array}$ & $\begin{array}{l}\text { "Bootstrapping" and } \\
\text { "friends, families, and fools" }\end{array}$ \\
\hline Marketing & $\begin{array}{l}\text { Changes in marketing mix } \\
\text { may be how new } \\
\text { opportunities manifest } \\
\text { themselves }\end{array}$ & $\begin{array}{l}\text { Marketing mix may } \\
\text { fundamentally change as a } \\
\text { result of new opportunities } \\
\text { that emerge }\end{array}$ \\
\hline $\begin{array}{l}\text { Sustaining Competitive } \\
\text { Advantages }\end{array}$ & $\begin{array}{l}\text { Speed, secrecy, and erecting } \\
\text { barriers to entry may } \\
\text { sustain advantages }\end{array}$ & $\begin{array}{l}\text { Tacit learning in path } \\
\text { dependent process may } \\
\text { sustain advantages }\end{array}$ \\
\hline
\end{tabular}

\section{LEADERSHIP}

While a variety of leadership skills may be important no matter what type of opportunity is being exploited, others may vary in importance, depending on whether the opportunity that is being exploited is discovered or created.

For example, expert leadership is likely to be important in exploiting discovery opportunities. Since discovery opportunities often have their seeds in pre-existing industries, the exploitation of discovery opportunities often relies on the individual's prior 
knowledge about markets and products. Thus, when exploiting a discovery opportunity it is important that the leader have specific knowledge and information associated with the opportunity (Shane, 2000). Indeed, the leader exploiting a discovery opportunity will often have superior knowledge about a particular market or industry, knowledge about how that industry was disrupted by an exogenous shock, and knowledge about how to exploit the resulting opportunities (Kirzner, 1997).

Expert leaders are also likely to have professional links within the market or industry where a discover opportunity is being exploited (Shane, 2000). Expert leaders will often have gained much of their knowledge and information from being embedded within the market or industry in which the opportunity was discovered. However, the expert leader in this setting will have a dual challenge; to make sure that there is a distinctiveness about the new opportunity, but also to understand how to efficiently navigate the exploitation process through the environment in which it is embedded (Romanelli, 1991).

Of course, it is unlikely that the type of substantive expertise about an industry or market that is available to those seeking to exploit discovery opportunities will be a basis of leadership for those who are cooperating to exploit creation opportunities. This is because the nature of the substantive expertise required to exploit a creation opportunity is typically only known after that opportunity has emerged from the enactment process. However, it will often be the case that those seeking to exploit a creation opportunity will need the cooperation of others well before the specific expertise that exploiting an opportunity requires is known.

In this setting, leadership is likely to emerge, not on the basis of the leader's substantive expertise, but instead based on the leader's experience in managing the enactment process, the ability that a leader has to inspire creativity and dedication under uncertain conditions, the extent to which followers believe they can trust a leader, and so forth. These are the attributes of a charismatic leader, rather than an expert leader (Weber, 1903). Charismatic leaders are more likely to be successful than expert leaders when cooperation is needed to exploit a creation opportunity (Alvarez and Barney, 2005).

None of this suggests that charismatic leadership will be irrelevant in discovery settings. Rather, it suggests that while charisma and expertise may both be important in discovery settings, that expert leadership is less likely to be important in creation settings. 


\section{DECISION MAKING}

Discovery theory assumes that entrepreneurs operate under conditions of risk. In this setting, entrepreneurs can, and should, apply a variety of risk-based data collection and analysis techniques, all of which are designed to collect the information required to estimate the risks associated with making a particular decision. Examples of such risk-based data collection techniques include the use of customer focus groups, customer surveys, the collection of information from government agencies, the collection of information from trade associations, and so forth. Armed with this information, entrepreneurs can apply traditional risk-based decision-making tools, including discounted present value techniques (Brealey and Myers, 1988), real options analysis (Kogut, 1991) and scenario analysis (Schoemaker, 1995) to make decisions about whether or not to exploit an opportunity. These tools all assume that entrepreneurs understand their opportunity costs, i.e., the value of the opportunities they forgo by exploiting one opportunity over another (Casson, 2003; Milgrom and Roberts, 1992).

Clearly, traditional risk-based data collection and analysis cannot be effectively applied in the uncertain setting assumed to exist in creation theory. Instead, entrepreneurs make decisions in other ways. For example, they may make decisions based on decision making heuristics or biases (Busenitz and Barney, 1997; Shepherd, McMullen and Jennings, 2007). Or, they may make decisions using an inductive, iterative, and incremental process such as effectuation (Sarasvathy, 2001) or bricolage (Baker and Nelson, 2005).

In a creation setting, it is also not possible for entrepreneurs to effectively calculate the opportunity costs associated with their actions. Instead of opportunity costs, creation theory suggests that entrepreneurs use the concept of "acceptable losses" to judge the downside associated with engaging in entrepreneurial actions (Sarasvathy, 2001). An acceptable loss is simply that value, both economic and personal, that potential entrepreneurs are willing to forgo if the actions they engage in happen to not lead to actual opportunities to produce new products or services. In this context, an entrepreneur engages in entrepreneurial actions when the total losses that can be created by such activities are not too large. According to creation theory, the potential gains from these activities-gains that cannot be anticipated even probabilistically-do not 
play a major role in deciding whether or not to engage in entrepreneurial actions.

Overall, when entrepreneurs make decisions using context appropriate tools, they will more effectively form and exploit opportunities than when they use context inappropriate tools to make decisions. Risk-based decision tools are more appropriate in discovery settings; inductive, iterative and incremental decision making, biases and heuristics, and acceptable loss are more appropriate in creation settings.

\section{Human Resource practices}

A wide variety of human resources practices may vary in their effectiveness, depending on whether the context within which an entrepreneur is operating is discovery or creation. Only one of these practices - recruitment-will be discussed here.

In a discovery context, entrepreneurs will generally be able to anticipate the specific kinds of skills they need to exploit an opportunity. This suggests that they will be able to effectively hire people with highly specialized human capital. Also, because entrepreneurs will be able to explain the nature of the opportunity they are exploiting to their potential employees, entrepreneurs will be able to effectively recruit widely, including outside of their current social networks.

In a creation context, entrepreneurs will not be able to anticipate the specific kinds of skills they will ultimately need to exploit the opportunity they form. Thus, it will not be possible to effectively hire new employees based on their specific expertise. Rather, in this context, entrepreneurs will find it to be more effective to hire individuals with broad human capital and individuals with a great deal of flexibility. Also, because it will be difficult to explain the nature of the opportunity that is being exploited to a potential employee, entrepreneurs in this setting will find recruitment among their current social networks more effective than recruiting more broadly.

Similar differences in the effectiveness of other human resource practices in discovery and creation contexts, besides recruitment, can also be identified and deserve additional attention. However, in general, when entrepreneurs manage their human resources in a context appropriate way, they will more effectively form and exploit opportunities than when they manage their human resources in context inappropriate ways. Recruiting specific human capital ex- 
pertise recruited broadly is more appropriate in discovery settings; recruiting flexible general human capital from pre-existing social networks is more appropriate in creation settings.

\section{Strategy}

Most entrepreneurs develop strategies (Brett, 2004; Delmar and Shane, 2003; Kuratko, 1991; Shane and Delmar, 2004). However, the effectiveness of these strategies, and the strategy making process, can vary significantly depending on the context within which an entrepreneur is operating, be it discovery or creation.

In a discovery context, there is usually sufficient ex ante information so that critical assumptions in a strategy can be evaluated, the financial and other implications of these assumptions anticipated, specific timelines for executing the strategy can be specified, the size of the market and the potential return can be estimated, and so forth. Of course, over time, some of these elements of the strategy may be modified. However, these modifications should seldom involve redefining the fundamental purposes or objectives of a business. Once in place, it will usually not be necessary for entrepreneurs to fundamentally alter the assumptions of their strategies since enough information can be collected to make reasonably accurate predictions about the nature of an opportunity and how it can be exploited (Delmar and Shane, 2004).

However, in creation contexts, strategy plays a very different role since current and historical information are not available or not useful in describing the nature of an opportunity. Indeed, entrepreneurs in this setting may find traditional forms of strategic planning to be harmful and perhaps even misleading. In creation theory, the task facing entrepreneurs is not so much combining pre-existing information and knowledge, but, rather, asking the right questions, designing new experiments, remaining flexible, and learning (Mintzberg, 1994). Indeed, too rigorous strategic planning under conditions of uncertainty can short circuit the opportunity enactment process (March, 1991; Weick, 1979). Only as this enactment process reaches its conclusion - that is, when the level of uncertainty facing an entrepreneur shifts from uncertain to risky - are more traditional forms of strategic planning likely to be helpful to these entrepreneurs.

Rather than elaborate strategy documents that include sophisticated financial projections and customer segmentation analyses, creation theory suggests that strategic plans developed in uncertain set- 
tings will be simpler guides to entrepreneurial behavior. In this perspective, optimization and sharply defined goals are replaced with an approach that acknowledges that each point along the way of enacting an opportunity may be unique. Strategies in this setting may suggest the general direction entrepreneurs think they are likely to be heading, but are subject to numerous fundamental changes.

When entrepreneurs develop strategies in a context appropriate way, they will more effectively form and exploit opportunities than when they develop strategies in context inappropriate ways. Detailed, relatively unchanging strategies are more appropriate in discovery settings; less detailed, more flexible strategies are more appropriate in creation settings.

\section{FinANCE}

Entrepreneurs must also obtain financing to realize their opportunities (Baeyens and Manigart, 2003). The effectiveness of financing options are likely to vary significantly depending upon whether or not an entrepreneur is operating under conditions of discovery theory or under conditions of creation theory.

Entrepreneurs operating under discovery conditions will often be able to obtain financing from external sources-including banks and venture capital firms. In this context, information asymmetries between an entrepreneur and its external capital sources should be either low or relatively easy to overcome. Entrepreneurs in this context will be able to explain to outside sources of capital the nature of the opportunities they are planning to exploit, the financial implications of exploiting these opportunities, and the riskiness of exploiting these opportunities (Sapienza and Gupta, 1994). This means that the external capital market for entrepreneurs operating under discovery conditions should be a relatively low cost source of capital (Admati and Pfleiderer, 1994).

However, in creation settings traditional external sources of capital-including banks and venture capital firms - are unlikely to provide financing for entrepreneurs (Bhide, 1992; Christensen, Anthony and Roth, 2004). In these conditions, the problem facing sources of capital is not information asymmetries; it is simply the lack of information. Entrepreneurs cannot explain to outside capital sources the nature of the opportunities they are going to exploit because they do not know this nature themselves. 
"Bootstrapping" is likely to be a much more common way to finance activities taking place under creation conditions. In "bootstrapping," entrepreneurs finance activities from their own wealth, or from the wealth of those closely associated with themthe triumvirate of "friends, family, and fools" (Bhide, 1992). These sources of capital invest in the entrepreneur-his or her character, ability to learn, flexibility, and creativity - not in a particular business opportunity an entrepreneur plans to exploit.

Indeed, Bhide (1992) argues that entrepreneurs operating in a creation context may actually damage their ability to grow and prosper if they obtain external funding. This is because external funding tends to force these entrepreneurs to exploit an identified opportunity, even if it turns out that that opportunity is not as valuable as anticipated, and even if it should have been abandoned in favor of an alternative opportunity.

When entrepreneurs finance their businesses in a context appropriate way, they will more effectively form and exploit opportunities than when they finance their businesses in context inappropriate ways. External bank or venture capital funding is more appropriate in discovery settings; bootstrapping is more appropriate in creation settings.

\section{MARKETING}

Marketing is an important activity for those seeking to exploit both discovery and creation opportunities. However, these marketing efforts may vary significantly in their effectiveness, depending on the context within which an entrepreneur is operating.

For example, entrepreneurs operating in a discovery context can effectively specify the product, price, distribution channel, promotion strategy, and customer service strategies they are likely to pursue. Indeed, exogenous shocks to an industry or market may have created opportunities precisely in these marketing areas. For example, technological changes may have made it possible to change product attributes in a significant way; changes in demand or production technology may have enabled an entrepreneur to lower (or increase) the price of the products or services it sells; political and technological changes may create new distribution opportunities for an entrepreneur; and so forth.

In a creation context, these exogenous shocks to an industry or market have not occurred. Here, instead of examining how ex- 
ogenous changes in an industry or market may have created opportunities in product, price, distribution, promotion, and customer service, an entrepreneur may use these attributes of the marketing mix to explore possible opportunities to create. For example, an entrepreneur in the creation process might alter the distribution model similar to what happened with the introduction of the internet. While not the only source of hypotheses about how to create opportunities, attributes of a marketing mix may be an important tool for generating such hypotheses.

\section{SUSTAINING COMPETITIVE ADVANTAGES}

Finally, the effectiveness of the strategies that entrepreneurs pursue in order to sustain any competitive advantages they gain from their entrepreneurial activities are likely to vary significantly, depending on the context within which an entrepreneur operates. For example, in a discovery context, information about an opportunity and how to exploit it is likely to become publicly available soon after the first entrepreneur is able to describe and exploit it. This will typically lead to rapid competitive imitation (Barney, 1991). Thus, if entrepreneurs are unable to erect barriers to entry into an industry (Porter, 1980), it is likely to be very difficult for entrepreneurs to sustain any competitive advantages they may have from exploiting an opportunity. This also suggests that once an entrepreneur in this setting becomes aware of an opportunity, that both the speed with which this opportunity is exploited, and the secrecy with which it is exploited, can have a significant impact on the profits it generates.

The erection of barriers to entry, secrecy, and speed of execution are likely to be much less competitively important to entrepreneurs operating in a creation context. The uncertainty in this context makes it unlikely that any potential competing entrepreneurs will know more about an opportunity, or will be able to collect information more effectively about an opportunity, then a particular entrepreneur. Moreover, the path dependent nature of the process of creating an opportunity is likely to generate tacit learning that entrepreneurs who have not gone through the creation process may not know (Arthur, 1989; Dierickx and Cool, 1989). In this sense, the very act of creating an opportunity may give an entrepreneur an advantage is sustaining any competitive advantages associated with that opportunity. This will be the case regardless of any 
barriers to entry entrepreneurs do or do not erect to protect their competitive advantages. Since such barriers are costly to create, it is unlikely that entrepreneurs operating in a creation setting will need to erect them.

When entrepreneurs act to sustain their competitive advantages in a context appropriate way, they will more effectively form and exploit opportunities than when they sustain their competitive advantages in context inappropriate ways. Barriers to entry, speed, and secrecy are more appropriate tools for sustaining competitive advantages in discovery settings; relying on path dependent tacit knowledge is a more appropriate tool in creation settings.

\section{Discussion}

This description of discovery and creation theory has a variety of important implications. Some of these implications are discussed here.

\section{DISCOVERY, CREATION AND THE FIELD OF ENTREPRENEURSHIP}

Recently, some management disciplines have been criticized for having too many theories, and not enough theoretical and empirical integration (Hambrick, 2005; Pfeffer, 2005). This paper suggests the opposite for the field of entrepreneurship. This is a field where only one opportunity formation and exploitation process has been systematically described in the literature-discovery theory. By more fully developing a second theoretical perspective-creation theory - the assumptions of both theories are made more explicit. This is likely to encourage a broader debate in the field of entrepreneurship.

For example, discovery theory-based research has asked a variety of important empirical questions about the formation and exploitation of opportunities, including: "How do changes in an industry create new opportunities?" "Are entrepreneurs that form and exploit opportunities really different than individuals who do not?" and "How do entrepreneurs estimate the riskiness of their decisions?" However, efforts to answer these discovery-inspired questions has left other questions - questions more consistent with creation theory - not just unanswered, but often not even asked. These questions include: "How does action by entrepreneurs create opportunities?" "Are differences between entrepreneurs who form and exploit opportunities and those that do not the cause, or effect, of entrepreneurial action?" and "How can entrepreneurs use incremental, iterative, and inductive processes to make decisions?" Early 
empirical efforts designed to answer some of these creation theory questions suggest significant potential in pursuing this line of work (e.g. Baker and Nelson, 2005).

Of course, suggesting that creation theory is a logical alternative to discovery theory does not imply that discovery theory should be abandoned in favor of creation theory. Rather, future research in entrepreneurship will need to carefully examine the context under which entrepreneurs are operating. When entrepreneurs operate in a discovery context, a variety of specific entrepreneurial actions are likely to be most effective; when they operate in a creation context, a different set of entrepreneurial actions are likely to be most effective. By acknowledging the importance of both theories, it will be possible to begin to articulate a truly general theory of entrepreneurship (Osigweh, 1989).

\section{CREATION AND EVOlUtionaRY THEORIES OF ENTREPRENEURSHIP}

The enactment process that is central to a creation theory of opportunity formation and exploitation can be understood as a micro-level process that underlies a broader evolutionary theory of entrepreneurship (Nelson and Winter, 1982). Indeed, in his discussion of the social psychology of enactment, Weick (1979) observes that enactment at the micro level can lead to evolutionary processes at the macro-level. Also, in their discussion of evolutionary theories of entrepreneurship, Aldrich and Ruef (2006) observe that macro organization-level evolution assumes some sort of enactment process at the micro level, of the type described by Weick (1979).

Obviously, the link between enactment, creation theory, and an evolutionary theory of entrepreneurship is underdeveloped in the current paper. However, it does seem at least possible that creation theory may ultimately provide a link between micro-level processes of enactment and macro-level processes of variation, selection, and retention. This link may be built on the informational characteristics of the settings within which entrepreneurs operate, and the impact of these settings on the relationship between entrepreneurial actions and the formation and exploitation of opportunities.

\section{Creation and Resource-BAsed Theory}

In a similar vein, creation theory may also address another important issue in resource-based theory in the field of strategic management. This theory examines the conditions under which 
heterogeneously distributed and costly to copy resources and capabilities can be sources of sustained competitive advantages for firms (Barney, 1986). While this theoretical perspective is beginning to receive significant empirical support (Barney and Arikan, 2001) an important question in resource-based theory remains unansweredwhere do heterogeneous resources come from (Barney, 2001)?

Creation theory provides one answer to this question. Under conditions of uncertainty, the enactment process can have the effect of exacerbating what were originally very small differences in the initial stages of opportunity formation to create quite substantial differences over time. This may be true of the kinds of resources and capabilities an entrepreneur and an entrepreneurial firm accumulate over the opportunity enactment process. In this sense, enactment can create heterogeneity in resources and capabilities which, in turn, can enable some firms to conceive of and implement strategies that other firms can neither conceive of nor implement. Put differently, opportunity enactment may create valuable, rare, and costly to imitate resources and capabilities that can then be used to implement strategies that generate sustained competitive advantage.

This link between creation theory and resource-based theory points to the central role of path dependence (Arthur, 1989), in creation theory, resource-based theory, and by implication, in evolutionary theory and theories of the social psychological enactment processes. In a sense, all these theories emphasize the importance of information and knowledge generated from the process of enacting an opportunity. As that process evolves differently for different individuals, teams, firms, and organizations these individuals or groups may become heterogeneous in costly to copy, and costly to reverse ways.

Of course, discovery theory also includes a notion of path dependence in its analysis of the formation and exploitation of entrepreneurial opportunities. In particular, discovery theory suggests that an individual's prior knowledge and experience with an industry or market can enable that individual to combine information in new ways to discover opportunities that could not have been discovered by individuals without this prior knowledge or experience.

While path dependence is important in both discovery theory and creation theory, there are important differences between these concepts as they are applied in these two theories. Path dependence in discovery theory might be thought of as first order path dependence: that the opportunities that are identified by the entrepreneur 
are linked to knowledge and information of an already existing path which influences the actions of the entrepreneur. In this view entrepreneurs continue along an already established path.

This type of first order path dependence also exists in creation theory. However, creation theory suggests the possibility of another type of path dependence. In this second type of path dependence, entrepreneurial action is not only affected by an existing path through time, it can create that path (Arthur, 1989). That is, creation theory suggests that entrepreneurial action can be both dependent variable - the thing affected by the path an entrepreneur takes over time-and independent variable-the actions taken by an entrepreneur that create this path in the first place (Dosi, 1984).

This second type of path dependence links creation theory to scholars that emphasize the role of founding conditions as a blueprint that determines a firm's initial form and subsequent evolution (Hannan and Freeman, 1977; Nelson and Winter, 1982). In this sense, creation theory suggests that a firm's founding conditions may themselves be the result of actions that entrepreneurs take to form and exploit an opportunity. Indeed, it may be in these early actions of the entrepreneur that the seeds of an organization's future form are sown.

\section{Creation and the Theory of the Firm}

While much of this paper assumes the individual as the unit of analysis, certainly the business processes identified can be scaled to the group, firm, or organization. In this sense the identification of creation theory may ultimately have implications for research on the theory of the firm (Alvarez and Barney, 2005). Currently popular theories of the firm-including transactions cost economics (Williamson, 1975, 1985) and incomplete contract theory (Hart and Moore, 1988) adopt the assumption that at the time a firm is created, parties to this exchange can either estimate the relative value of transaction specific investments they must make to complete an exchange (for transactions cost theory) or estimate who has the most to gain from that exchange (for incomplete contract theory). Of course, in the uncertainty conditions described in creation theory, it is unlikely that those contemplating the founding of an entrepreneurial firm will be able to know this information, especially early in the opportunity enactment process. 
In such settings, is it necessary to found entrepreneurial firms? And if the answer to this question is yes, then how is this done-when the value of specific investments and who has the most to gain from an exchange cannot be known. It may be necessary to identify different bases for creating firms when entrepreneurs seek to create firms in a creation context.

\section{REFERENCES}

ADMATI, A. R., PFLEIDERER P. 1994. Robust financial contracting and the role of venture capitalists. Journal of Finance. 1994; 49(2): 371-402.

ALDRICH, H. E., KENWORTHY, A. L. The accidental entrepreneur: Campbellian antinomies and organizational foundings. In: Baum,J. A. C.; McKelvey, B. (eds.). Variations in Organization Science: In Honor of Donald T. Campbell: 19-33. Sage: Thousand Oaks, CA, 1999.

ALDRICH, H. E., RUEF, M. Organizations Evolving (2nd ed.). Sage: Thousand Oaks, CA, 2006 .

ALVAREZ, S. A., BARNEY, J. How entrepreneurs organize firms under conditions of uncertainty. Journal of Management. 2005; 31(5): 776-93.

ARROW, K, J. The Limits of Organization. W. W. Norton: New York, 1974.

ARTHUR, W. B. Competing technologies, increasing returns, and lock-in by historical events. Economic Journal. 1989; 99(394): 116-131.

AZEVEDO, J. Updating organizational epistemology. In: Baum, J. A. C. (ed.). Companion to Organizations: 715-732. Oxford: Blackwell Publishers Ltd., 2002.

BAEYENS, K., MANIGART, S. Dynamic Financing Strategies: The Role of Venture Capital. Journal of Private Equity. 2003; 7(1): 50-58.

BAKER, T., NELSON, R. Creating something from nothing: Resource construction through entrepreneurial bricolage. Administrative Science Quarterly. 2005; 50: 329-366.

BALAKRISHNAN, S., WERNERFELT, B.. Technical Change, Competition and Vertical Integration. Strategic Management Journal. 1986; 7(4): 347-360.

BARNEY, J. Firm Resources and Sustained Competitive Advantage. Journal of Management. 1991; 17(1): 99-120.

BARNEY, J. B. Strategic factor markets: expectations, luck, and business strategy. Management Science. 1986; 32(10): 1231-41.

BARNEY, J. B. Is the resource-based 'view' a useful perspective for strategic management research? Yes. Academy of Management Review. 2001; 26(1): 41-56.

BARNEY, J. B, ARIKAN A. The resource-based view: Origins and implications. In M Hitt, RE Freeman, J Harrison (Eds.), The Blackwell Handbook of Strategic Managment: 124-188. Malden, MA: Blackwell Publishers, 2001. 
BERGER, P.L., LUCKMANN, T. The Social Construction of Reality. A Treatise in the Sociology of Knowledge. Garden City, NY: Anchor Books Doubleday, 1967.

BERGMANN, G. Philosophy of Science. University of Wisconsin Press: Madison, 1957. BHIDE ,A. Bootstrap Finance: The Art of Start-ups. Harvard Business Review. 1992; 70(6): 109-117. BHIDE, A. How Entrepreneurs Craft Strategies That Work. Boston: Harvard Business School Press, 1999.

BREALEY, R, MYERS, S. Principles of Corporate Finance. New York: McGraw-Hill, 1988.

BRETT, M. P. If You Fail to Plan, Do You Plan to Fail? Academy of Management Executive. 2004; 18(4): 156-157.

BUSENITZ, L. W, BARNEY, J, B. Differences between entrepreneurs and managers in large organizations: Biases and heuristics in strategic decision making. Journal of Business Venturing. 1997; 12(1): 9-30.

CAMPBELL, D. T. Blind variation and selective retention in creative thought as in other knowledge processes. Psychological Review. 1960; 67(6): 380-400.

CASSON, M. The entrepreneur: An economic Theory (2nd ed.). Oxford: Edward Elgar, 1982.

CASSON, M. Entrepreneurship, business culture and the theory of the firm. In ZJ Acs, DB Audretsch (Eds.), Handbook of Entrepreneurship Research: An Interdisciplinary Survey and Introduction. Dordrecht, Netherlands: Kluwer Academic Publishers, 2003.

CHOI, Y.B. Paradigms and Conventions: Uncertainty, Decision Making and Entrepreneurship. University of Michigan Press: Ann Arbor, 1993.

CHRISTENSEN, C. M., ANTHONY S. D., ROTH, E. A. Seeing What's Next. Boston; Harvard Business School Press, 2004.

CYERT, R. M., MARCH, J. G. A Behavioral Theory of the Firm. Englewood Cliffs, NJ: Prentice Hall, 1963.

DELMAR F, SHANE S. 2003. Does business planning facilitate the development of new ventures? Strategic Management Journal 24(12): 1165-1185.

DELMAR, F, SHANE, S. Legitimating first: Organizing activities and the survival of new ventures. Journal of Business Venturing. 2004; 19: 385-410.

DEQUECH, D. Uncertainty and Economic Sociology. American Journal of Economics $\mathcal{E}$ Sociology. 2003; 62(3): 509.

DIERICKX, I, COOL, K. Asset stock accumulation and sustainability of competitive advantage. Management Science. 1989; 35: 1504-1511.

DIMAGGIO, P., POWELL, W. The iron cage revisited: institutional isomorphism and collective rationality in organizational fields. American Sociological Review. 1983; 48: 147-160.

DOSI, G. Technical Change and Industrial Transformation. New York: St. Martins Press, 1984.

DOSI, G. Sources, procedures, and microeconomic effects of innovation. Journal of Economic Literature. 1988; 26(4): 1120-1171. 
DUNNING, D, HEATH, C, SULS, J. M. Flawed Self-assessment. Psychological Sciences in the Public Interest. 2004; 5(3): 69-106.

ETZIONI, A. The epigenesis of political communities at the international level. The American Journal of Sociology. 1963; 68(4): 407-421.

GAGLIO, C. M., KATZ, J. A. The Psychological Basis of Opportunity Identification: Entrepreneurial Alertness. Small Business Economics. 2001; 16(2): 95.

GARTNER, W.B. A conceptual framework for describing the phenomenon of new venture creation. Academy of Management Review. 1985; 10: 696-706.

HAMBRICK, D. C. Just How Bad Are Our Theories? A Response to Ghoshal. Academy of Management Learning \& Education. 2005; 4(1): 104.

HANNAN, M. T., FREEMAN, J. The Population Ecology of Organizations. American Journal of Sociology. 1977. 82: 50-73.

HART, O., MOORE, J. Incomplete contracts and renegotiation. Econometrica. 1988; 56(4): 755-786.

HAYWARD, M., SHEPHERD, D. A., GRIFFIN, D. A hubris theory of entrepreneurship. Management Science. 2006; 52(1): 160-172.

HERZBERG, F. The Managerial Choice: To be Efficient and to be Human. Homewood, IL: DowJones-Irwin, 1976.

KIRZNER, I. Competition and Entrepeneurship. Chicago and London: University of Chicago Press, 1973.

KIRZNER, I. M. Entrepreneurial discovery and the competitive market process: an Austrian approach. Journal of Economic Literature. 1997; 35(1): 60-85.

KNIGHT, F. H. Risk, Uncertainty and Profit. New York: Houghton Mifflin, 1921.

KOGUT, B.. Joint ventures and the option to expand and acquire. Management Science. 1991; 37: 19-33.

KURATKO, D. F. Demystifying the business plan process: An introductory guide. Small Business Forum Winter. 1991; (3): 33-40.

LANGLOIS, R. N, COSGEL, M. M. Frank knight on risk, uncertainty, and the firm: A new interpretation. Economic Inquiry. 1993; 31(3): 456-465.

LESSER, A. Functionalism in Social Anthropology. American Anthropologist. 1935; 37: 386-393.

LEVINTHAL, D. Adaptation on Rugged Landscapes. Management Science. 1997; 43(7): 934-950.

LOASBY, B. J. The organizational basis of cognition and the cognitive basis of organization. In M Augier, JG March (Eds.), The economics of choice, change and organization, essays in memory of Richard M. Cyert: 147-167. Cheltenham, UK: Edward Elgar, 2002.

LOW, M. B., MACMILLAN, I. C. Entrepreneurship: Past research and future challenges. Journal of Management. 1988; 14(2): 139-161.

MARCH, J. G. Exploration and exploitation in organizational learning. Organization Science. 1991; 2(1): 71- 87. 
MARCH, J. G, SIMON, H. A. Organizations. New York: John Wiley, 1958.

MASLOW, A. A theory of human motivation. Psychological Review. 1943; 50: 370-396.

MCCLELLAND, D. The achieving society. Princeton, NJ: Van Nostrand, 1961.

MCKELVEY, B. Toward a Campbellian realist organization science. In J Baum, B McKelvey (Eds.), Variations in Organization Science: In Honor of Donald T. Campbell. 1999; 383-411. Sage: Thousand Oaks.

MILGROM, P., ROBERTS, J. Economics, Organization \& Management. New York: Prentice Hall, 1992.

MILLER, K. D. Risk and rationality in entrepreneurial processes. Strategic Entrepreneurship Journal this issue, 2007.

MINTZBERG, H. The Rise and Fall of Strategic Planning. Boston: Free Press, 1994.

MOSAKOWSKI, E. Strategy Making under Causal Ambiguity: Conceptual Issues and Empirical Evidence. Organizationn Science. 1997; 8(4): 414-442.

NAGAL, E. The Structure of Science. New York: Harcourt, Brace \& World, 1961.

NELSON, R., WINTER, S. An Evolutionary Theory of Economic Change. Cambridge, MA: Belknap Press, 1982.

OSIGWEH, C. A. Concept falibility in organizational science. Academy of Management Review. 1989; 14(4): 579-594.

PARSONS T. The Social System. New York: Free Press, 1951.

PARSONS, T., SHILS, E. Toward a General Theory of Action. Cambridge: Harvard University Press, 1962.

PFEFFER, J. Why Do Bad Management Theories Persist? A Comment on Ghoshal. Academy of Management Learning \& Education. 2005; 4(1): 96-100.

PORTER, M. E. Competitive Strategy. New York: Free Press, 1980.

ROMANELLI, E. The evolution of new organizational forms. American Review of Sociology. 1991; 17: 79-103.

SAPIENZA, H. J., GUPTA, A. K. Impact of agency risks and task uncertainty on venture capitalist-CEO interaction. Academy of Management Journal. 1994; 37(6): 1618-1632.

SARASVATHY, S. D. Causation and effectuation: toward a theoretical shift from economic inevitability to entrepreneurial contingency. Academy of Management Review. 2001; 26(2): 243-263.

SCHOEMAKER, P. J. H. Scenario Planning: A Tool for Strategic Thinking. Sloan Management Review. 1995; 36(2): 25-40.

SCHUMPETER, J. A. Theory of economic development: An inquiry into profits, capital, credit, interest and the business cycle. Cambridge: Harvard University Press, 1934.

SCHUMPETER, J. A. Business Cycles. A Theoretical, Historical, and Statistical Analysis of the Capitalist Process. New York and London: McGraw-Hill, 1939. 
SCOTT, W. R. Institutions and Organizations. 2nd edition. Thousand Oaks, California: Sage: 2001.

SHANE, S. Prior Knowledge and the Discovery of Entrepreneurial Opportunities. Organization Science. 2000, 11(4): 448-470.

SHANE, S. A General Theory of Entrepreneurship. The individual-opportunity Nexus. Edward Elgar: Northampton, MA, 2003.

SHANE, S., DELMAR, F. Planning for the market: business planning before marketing and the continuation of organizing efforts. Journal of Business Venturing. 2004; 19(6): 767-785.

SHANE, S, VENKATARAMAN, S. The promise of entrepreneurship as a field of research. Academy of Management Review. 2000; 25(1): 217.

SHEPHERD, D. A., MCMULLEN, J. S., JENNINGS, P. D.The formation of opportunity beliefs: Overcoming ignorance and reducing doubt. Strategic Entrepreneurship Journal this issue, 2007.

VENKATARAMAN, S. Foreword. In S. SHANE, A General Theory of Entrepreneurship. The Individual-Opportunity Nexus: xi-xii. Northampton, MA: Edward Elgar, 2003.

WEBER M. The Methodology of the Social Sciences. New York: Free Press, 1903.

WEICK, K. E. The Social Psychology of Organizing. Reading, MA: Addison-Wesley, 1979.

WERNERFELT, B., KARNANI, A. Competitive strategy under uncertainty. Strategic Management Journal. 1987; 8(2): 187-194.

WILLIAMSON, O. E. Markets and hierarchies: Analysis and antitrust implications. New York: Free Press, 1975.

WILLIAMSON, O. E. The economic institutions of capitalism. New York: Free Press, 1985.

Recebido em 8/8/07.

Aceito em 10/11/07. 